\title{
Accidental apixaban intoxication in a 23- month-old child: a case report
}

\author{
Manon Launay ${ }^{1 *} \mathbb{D}$, Yara Nasser ${ }^{1}$, Isabelle Maubert ${ }^{2}$, Anne-Cécile Chaux ${ }^{3}$ and Xavier Delavenne ${ }^{1,4}$
}

\begin{abstract}
Background: Direct oral anticoagulants, such as apixaban, are increasingly used in everyday practice in order to treat or prevent thromboembolic diseases. To date, there is no available data about apixaban pharmacokinetics in children, and no intoxication has previously been described.

Case presentation: A 23-month-old boy, with no medical history, was admitted to the emergency department $2 \mathrm{~h}$ after accidentally ingesting $40 \mathrm{mg}$ apixaban and $0.75 \mathrm{mg}$ digoxin. No adverse event was observed. Digoxin trough level was within therapeutic values. Apixaban blood concentration increased up to $1712 \mu \mathrm{g} / \mathrm{L}$ at $\mathrm{H}+6$ (1000$2750 \mu \mathrm{g} / \mathrm{L}$ using $2-5 \mathrm{mg} / \mathrm{kg}$ of apixaban in adults). The terminal half-life was $8.2 \mathrm{~h}$ ( $6-15 \mathrm{~h}$ in adults). The rapid elimination may explain the absence of bleeding despite high concentrations.

Conclusions: Despite an important intake of apixaban and a real disturbance in routine coagulation assays, no clinical sign of bleeding was observed, perhaps due to wide therapeutic range of apixaban. It may also be explained by its rapid elimination. Considering the high Cmax and a possible enteroenteric recycling, the use of activated charcoal should be considered in such situations in order to prevent eventual bleeding.
\end{abstract}

Keywords: Apixaban, DOAC, Pediatrics, Intoxication, Pharmacokinetics, Child, Overdose, Digoxin, Case report

\section{Background}

Direct oral anticoagulants, such as apixaban, are increasingly used in everyday practice in order to treat or prevent thromboembolic diseases $[1,2]$. Apixaban is a reversible and selective FXa inhibitor (activated factor X) and inhibits free, clot-bound FXa, and prothrombinase activity [3]. Apixaban has linear pharmacokinetics, and concentration-related pharmacodynamic effects have been described in adults [4]. Many clinical cases reported severe self-poisoning with apixaban among adult patients [5-9]. To date, there is no available data about apixaban pharmacokinetics in children, and no intoxication has previously been described. Digoxin, on

\footnotetext{
* Correspondence: manon.launay@chu-st-etienne.fr

'Laboratoire de Pharmacologie-Toxicologie-Gaz du Sang, CHU Saint-Etienne, Albert Raimond avenue, Saint-Etienne, France

Full list of author information is available at the end of the article
}

the other hand, is better known in pediatrics as it is commonly used for arrhythmias and heart failure treatment.

\section{Case presentation}

A 23 -month-old boy $(12.9 \mathrm{Kg})$, with no medical history, was admitted to the emergency department $2 \mathrm{~h}$ after accidentally ingesting 8 pills of apixaban $5 \mathrm{mg}(40 \mathrm{mg})$ and 3 pills of digoxin $0.25 \mathrm{mg}(0.75 \mathrm{mg})$. His clinical exam was normal. No hemorrhagic sign was identified. His heart rate (105 pulsations/minute) and the ECG were normal. The child remained under medical supervision for $48 \mathrm{~h}$. Four blood tests were withdrawn during hospitalization at 2, 6, 21.5 and $48 \mathrm{~h}$ after the ingestion $(\mathrm{H}+2, \mathrm{H}+6, \mathrm{H}+21.5, \mathrm{H}+48)$, for digoxin concentrations monitoring and routine coagulation assays. After $\mathrm{H}+6$, the child was transferred to the University Hospital of Saint Etienne, where apixaban monitoring was available using a published Liquid Chromatography-

(C) The Author(s). 2020 Open Access This article is licensed under a Creative Commons Attribution 4.0 International License, which permits use, sharing, adaptation, distribution and reproduction in any medium or format, as long as you give appropriate credit to the original author(s) and the source, provide a link to the Creative Commons licence, and indicate if changes were made. The images or other third party material in this article are included in the article's Creative Commons licence, unless indicated otherwise in a credit line to the material. If material is not included in the article's Creative Commons licence and your intended use is not permitted by statutory regulation or exceeds the permitted use, you will need to obtain permission directly from the copyright holder. To view a copy of this licence, visit http://creativecommons.org/licenses/by/4.0/ The Creative Commons Public Domain Dedication waiver (http://creativecommons.org/publicdomain/zero/1.0/) applies to the data made available in this article, unless otherwise stated in a credit line to the data. 
Mass Spectrometry method [10]. Apixaban monitoring was initiated at $\mathrm{H}+21.5$. Apixaban concentrations were also retrospectively analyzed at $\mathrm{H}+2$ and $\mathrm{H}+6$. The renal function was normal and remained stable (Creatinine between 17 and $24 \mu \mathrm{mol} / \mathrm{L}$ (normal range: $15-35 \mu \mathrm{mol} / \mathrm{L}$ [11])). No clinical sign of bleeding was observed. Apixaban concentration increased up to $1712 \mu \mathrm{g} / \mathrm{L}$ at $\mathrm{H}+6$, then decreased to $7 \mu \mathrm{g} / \mathrm{L}$ at $\mathrm{H}+48$ (Fig. 1). Apixaban was eliminated with a terminal half-life of $8.2 \mathrm{~h}$ and its distribution volume indexed to bioavailability was $23 \mathrm{~L}$ or $1.8 \mathrm{~L} / \mathrm{Kg}$. As expected, aPTT ratio (activated partial thromboplastin time ratio: Patient aPTT (sec) /Normal plasma aPTT (sec)) and PT were prolonged [4] (Fig. 1).

Regarding digoxin, the concentration at $\mathrm{H}+2$ was $5.9 \mu \mathrm{g} / \mathrm{L}$ and decreased to $0.4 \mu \mathrm{g} / \mathrm{L}$ at $\mathrm{H}+48$. Digoxin was eliminated with a half-life of approximatively $15.6 \mathrm{~h}$.

The patient left the hospital after $48 \mathrm{~h}$ without any complication or sequelae.

\section{Discussion/conclusion}

To our knowledge, this is the first case reporting apixaban intoxication in children. Apixaban blood concentration increased up to a high level of $1712 \mu \mathrm{g} / \mathrm{L}$ at $\mathrm{H}+6$ after ingesting $40 \mathrm{mg}$ of apixaban $(3.1 \mathrm{mg} / \mathrm{Kg})$. Cmax was consistent with data in adults overdose (between 1000 and $2750 \mu \mathrm{g} / \mathrm{L}$ after ingesting 2 to $5 \mathrm{mg} / \mathrm{kg}$ of apixaban) $[5,6]$.

Despite multiple ongoing studies on apixaban in the pediatric population [12-15], there is currently no available data on apixaban pharmacokinetics and pharmacodynamics properties among children. As previously reported, the apixaban plasma concentration vs. time profile exhibited a multiphasic elimination profile, with an initial rapid decline followed by a more gradual terminal phase [4]. Apixaban was eliminated with a terminal half-life of $8.2 \mathrm{~h}$. The half-life described in adults overdose was between $6 \mathrm{~h}$ and $15 \mathrm{~h}$ depending on the patient and other co-administered drugs [6-9]. The rapid elimination may explain the absence of bleeding despite high concentrations. The results observed during the clinical development of new oral anticoagulants have shown that the inexplicable variability of drug response is quite low in highly selected populations, so there is no sense in recommending drug monitoring for such patients. However, sources of inter- and intra-individual variability (such as renal and/or hepatic function, advanced age, relevant drugdrug interaction, ...) have been identified, concerning a restricted population at very high risk of clinical events [16]. Drug overdose could also be at high risk of clinical event and the monitoring of apixaban concentrations should be assessed for these patients, if available. As no apixaban dosage was performed within the first $20 \mathrm{~h}$ after the ingestion, the patient was followed-up with PT and aPTT ratio monitoring. As expected, because apixaban is a reversible anti-Xa with concentrationrelated pharmacodynamic effects, aPTT ratio and PT were prolonged with an interesting overlap as shown in Fig. 1. Thus, routine coagulation assays could be monitored when apixaban monitoring is not available. The
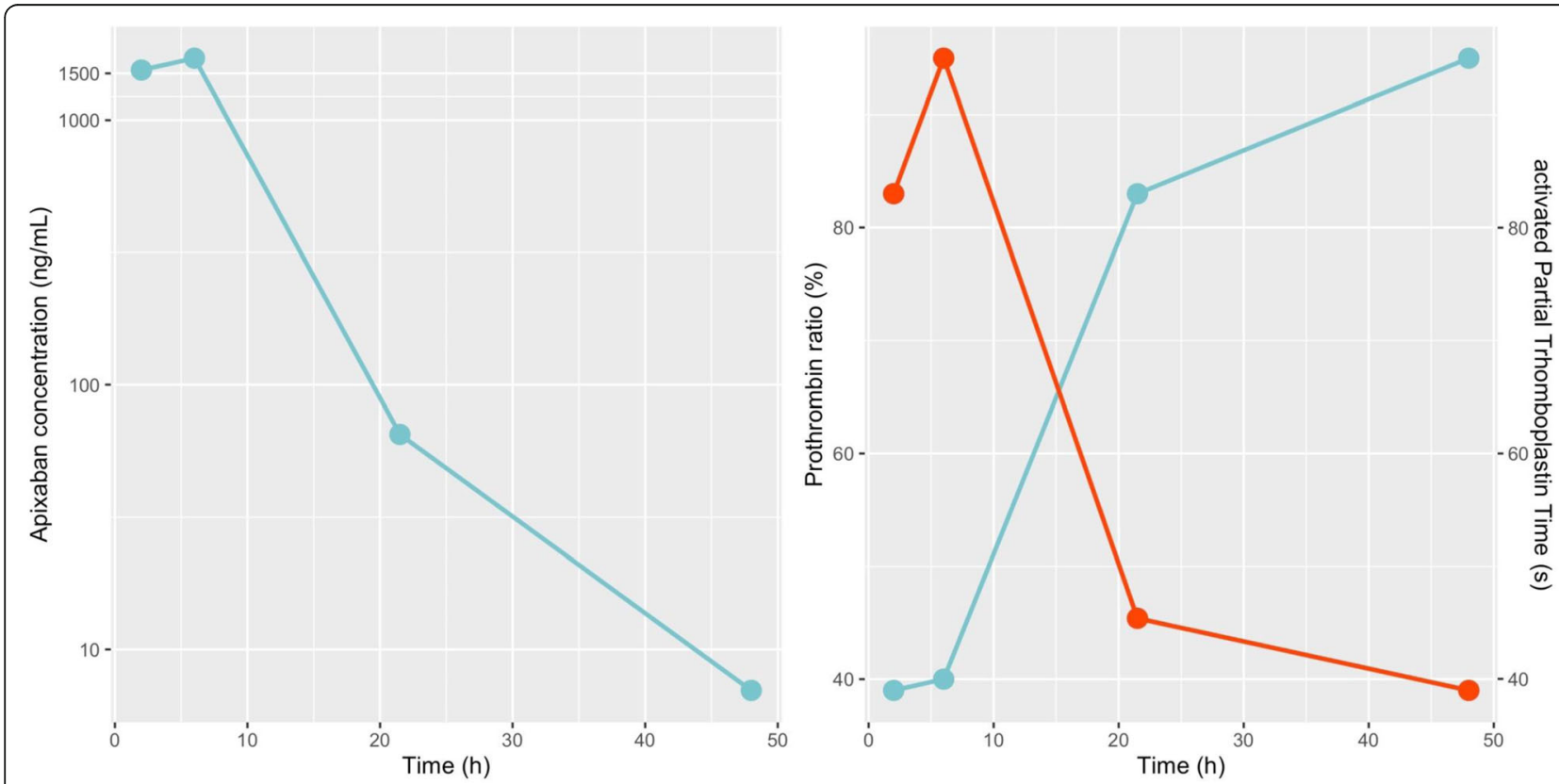

Fig. 1 Variation of apixaban ( $\mu \mathrm{g} / \mathrm{L})$, PT (\%) (blue line) and aPTT ratio (red line) of a 23-month-old child at different times after accidentally ingesting $40 \mathrm{mg}$ of apixaban and $0.75 \mathrm{mg}$ of digoxin 
distribution volume indexed to bioavailability was markedly different than the one reported in adults, $23 \mathrm{~L}$ vs $73 \mathrm{~L}$ in adults, or $1.8 \mathrm{~L} / \mathrm{Kg}$ vs $0.9 \mathrm{~L} / \mathrm{Kg}$ [4].

Furthermore, a peak concentration was probably reached between $\mathrm{H}+2$ and $\mathrm{H}+6$ and apixaban was still detectable at $\mathrm{H}+48$ (Fig. 1), with a possible enteroenteric recycling (i.e., reabsorption of drug excreted from the systemic circulation directly into the intestine) [17]. The use of activated charcoal in similar cases would be interesting in order to prevent eventual bleeding. A $28 \%$ decrease in apixaban exposure was indeed observed following administration of activated charcoal at $6 \mathrm{~h}$ post-dose [17]. Apixaban monitoring was done retrospectively in this case, and no antidote was administered but no side effect was reported.

The patient has also ingested $0.75 \mathrm{mg}(0.06 \mathrm{mg} / \mathrm{kg})$ of digoxin when the mean therapeutic dose is around 0.01 $\mathrm{mg} / \mathrm{kg} /$ day for children [18-20]. The half-life was $15.6 \mathrm{~h}$, a figure markedly shorter than the described half-life in the pediatric population $(36 \mathrm{~h})[18,19]$. Digoxin pharmacokinetic parameters have indeed already shown extensive variation in children, with clearance ranging from 6.0 to $3331.8 \mathrm{~mL} / \mathrm{kg} / \mathrm{h}$ [21]. Digoxin level at $24 \mathrm{~h}$ was $1.3 \mu \mathrm{g} / \mathrm{L}$, which is an usual therapeutic value [18-20, $22]$, and no adverse event was observed. Toxicity (such as nausea, vomiting and ECG abnormalities, etc.) is indeed frequently reported for trough level greater than $2 \mu \mathrm{g} / \mathrm{L}[20,22]$.

Despite an important intake of apixaban and a real disturbance in routine coagulation assays, no clinical sign of bleeding was observed, perhaps due to wide therapeutic range of apixaban. It may also be explained by its rapid elimination. Considering the high Cmax and a possible enteroenteric recycling, the use of activated charcoal should be considered in such situations in order to prevent eventual bleeding.

\section{Abbreviations}

aPTT: activated partial thromboplastin time; FXa: activated factor $X$

\section{Acknowledgements}

Not applicable.

\section{Authors' contributions}

A-C.C collected clinical data, Y. N, ML and IM collected biological data, M. L, Y. N, X. D contributed to data interpretation and writing of manuscript; all authors contributed to reviewed and approved the final version of the manuscript.

\section{Funding}

None.

\section{Availability of data and materials}

The data that support the findings of this study are available from the corresponding author upon reasonable request.

\section{Consent for publication}

A written and signed consent to publish the information was obtained from the guardians prior to submission.

\section{Competing interests}

None.

\section{Author details}

${ }^{1}$ Laboratoire de Pharmacologie-Toxicologie-Gaz du Sang, CHU Saint-Etienne, Albert Raimond avenue, Saint-Etienne, France. ${ }^{2}$ Laboratoire d'analyses médicales, CH Emile Roux, le Puy-en-Velay, France. ${ }^{3}$ Service de Médecine Intensive et Réanimation Pédiatrique, CHU Saint-Etienne, Saint-Etienne, France. ${ }^{4}$ INSERM U1059, Dysfonctions Vasculaires et de I'Hémostase, Université de Lyon, Saint-Etienne, France.

Received: 30 September 2020 Accepted: 30 November 2020

Published online: 05 December 2020

\section{References}

1. Gross PL, Weitz Jl. New anticoagulants for treatment of venous thromboembolism. Arterioscler Thromb Vasc Biol. 2008;28:380-6. https://doi. org/10.1161/ATVBAHA.108.162677.

2. Metha RS. Novel oral anticoagulants for prophylaxis and treatment of venous thromboembolism: part I (factor Xa inhibitors) expert. Rev Hematol. 2019;3:227-41

3. Wieland E, Shipkova M. Pharmacokinetic and Pharmacodynamic drug monitoring of direct-acting Oral anticoagulants: where do we stand? Ther Drug Monit. 2019;41(2):180-91.

4. Frost C, Wang J, Nepal S, Schuster A, Barett YC, Mosqueda-Garcia R, Reeves RA, LaCreta F. Apixaban, an oral, direct factor Xa inhibitor: single dose safety, pharmacokinetics, pharmacodynamics and food effect in healthy subjects. Br J Clin Pharmacol. 2013;75(2):476-87.

5. Ilicki J, Höjer J, Djärv T. Massive apixaban overdose - a comparison of three cases. Am J Emerg Med. 2018;36(5):891-3. https://doi.org/10.1016/j.ajem. 2017.09.035.

6. Franck B, Dulaurent S, El Balkhi S, Monchaud C, Picard N, Couderc S, Marquet P. Saint-Marcoux F. Woillard JB. Self-poisoning with 60 tablets of Apixaban, a pharmacokinetics case report. Br J Clin Pharmacol. 2019;85(1): 270-2. https://doi.org/10.1111/bcp.13790.

7. Barton J, Wong A, Graudins A. Anti-Xa activity overdose: a case report. Clin Toxicol. 2016:20(9):1-6.

8. Mast L, Rj V, Reijnen R, van Rossen RCJM, Overdiek JWPM, Wilms EB. Apixaban auto-intoxication: Toxicokinetics and coagulation tests. Thromb Haemost. 2017:117:2209-11. https://doi.org/10.1160/th17-07-0474.

9. Leikin SM, Patel H, Welker KL, Leikin JB. The X factor: lack of bleeding after an acute apixaban overdose. Am J Emerg Med. 2017;35(05):801.e5-6. https://doi.org/10.1016/j.ajem.2016.11.035.

10. Delavenne X, Mismetti P, Basset T. Rapid determination of apixaban concentration in human plasma by liquid chromatography /tandem mass spectrometry: application to pharmacokinetic study. J Pharm Biomed Anal. 2013;78-79:150-3. https://doi.org/10.1016/j.jpba.2013.02.007.

11. Pottel H, Vrydags N, Mahieu B, Vandewynckele E, Croes K, Martens F. Establishing age/sex related serum creatinine reference intervals from hospital laboratory data based on different statistical methods. Clin Chim Acta. 2008:396(1-2):49-55. https://doi.org/10.1016/j.cca.2008.06.017.

12. Von Vajna E, Alam R, So TY. Current clinical trials on the use of direct Oral anticoagulants in the pediatric population. Cardiol Ther. 2016:5:19-41. https://doi.org/10.1007/s40119-015-0054-y.

13. Radulescu VC. Anticoagulation therapy in children. Semin Thromb Hemost. 2017:43:877-85. https://doi.org/10.1055/s-0036-1598004.

14. Payne M, Burns K, Glatz A, Li D, Li X, Monagle P, Newburger J, Swan E, Wheaton O, Male C. A multi-national trial of a direct oral anticoagulant in children with cardiac disease: design and rationale of the safety of ApiXaban on pediatric heart disease on the preventioN of embolism (SAXOPHONE) study. Am Heart J. 2019;217:52-63. https://doi.org/10.1016/j. ahj.2019.08.002.

15. O'Brien SH, Li D, Mitchell LG, Hess T, Zee P, Yee DL, Newburger JW, Sung L, Rodriguez V. PREVAPIX-ALL: Apixaban compared to standard of Care for Prevention of venous thrombosis in Paediatric acute lymphoblastic Leukaemia (ALL)-rationale and design. Thromb Haemost. 2019:119(5):844_ 53. https://doi.org/10.1055/s-0039-1679938. 
16. Mismetti P, Laporte S. New oral antithrombotics: a need for laboratory monitoring. For J Thromb Haemost. 2010;8(4):621-6.

17. Wang X, Mondal S, Wang J, Tirucherai G, Zhang D, Boyd RA, et al. Effect of activated charcoal on apixaban pharmacokinetics in healthy subjects. Am J Cardiovasc Drugs. 2014;14:147-54. https:/doi.org/10.1007/s40256-013-0055-y.

18. Hastreiter AR, van der Horst RL, Voda C, Chow-Tung E. Maintenance digoxin dosage and steady-state plasma concentration in infants and children. J Pediatr. 1985;107(1):140-6. https://doi.org/10.1016/s0022-3476(85)80636-3.

19. EL Desoky ES, Nagaraja NV, Derendorf H. Population pharmacokinetics of digoxin in Egyptian pediatric patients: impact of one data point utilization. Am J Ther. 2002;9(6):492-8. https://doi.org/10.1097/00045391-20021 1000-00006.

20. Zalzstein E, Zucker N, Lifshitz M. Digoxin concentration in saliva and plasma in infants, children, and adolescents with heart disease. Curr Ther Res Clin Exp. 2003;64(9):743-9. https://doi.org/10.1016/j.curtheres.2003.09.015.

21. Lares-Asseff I, Juárez-Olguín H, Flores-Pérez J, Bobadilla-Chávez J. Pharmacokinetics of digoxin in children with congestive heart failure aggravated by other diseases. Rev Investig Clin. 2004;56(1):32-7.

22. Moffett BS, Garner A, Zapata T, Orcutt J, Niu M, Lopez KN. Serum digoxin concentrations and clinical signs and symptoms of digoxin toxicity in the paediatric population. Cardiol Young. 2016;26(03):493-8. https://doi.org/10 1017/s1047951115000505.

\section{Publisher's Note}

Springer Nature remains neutral with regard to jurisdictional claims in published maps and institutional affiliations.

Ready to submit your research? Choose BMC and benefit from:

- fast, convenient online submission

- thorough peer review by experienced researchers in your field

- rapid publication on acceptance

- support for research data, including large and complex data types

- gold Open Access which fosters wider collaboration and increased citations

- maximum visibility for your research: over $100 \mathrm{M}$ website views per year

At $\mathrm{BMC}$, research is always in progress.

Learn more biomedcentral.com/submissions 